\title{
Some comments on using of Web of Science Core Collection for bibliometric studies in Ann Transl Med. Vol. 8
}

\author{
Yuh-Shan Ho \\ Trend Research Centre, Asia University, Taichung 41354, Taiwan \\ Correspondence to: Yuh-Shan Ho. Trend Research Centre, Asia University, No. 500, Lioufeng Road, Wufeng, Taichung 41354, Taiwan. \\ Email: ysho@asia.edu.tw. \\ Comment on: Fang J, Pan L, Gu QX, et al. Scientometric analysis of mTOR signaling pathway in liver disease. Ann Transl Med 2020;8:93. \\ Liang MM, Meng Y, Zhou SM, et al. Research hotspots and trends analysis of ankylosing spondylitis: A bibliometric and scientometric analysis from \\ 2009 to 2018. Ann Transl Med 2020;8:1445. \\ Li YZ, Wang XJ, Thomsen JB, et al. Research trends and performances of breast reconstruction: A bibliometric analysis. Ann Transl Med \\ 2020;8:1529.
}

Submitted Jun 03, 2021. Accepted for publication Jul 15, 2021.

doi: 10.21037/atm-21-2881

View this article at: https://dx.doi.org/10.21037/atm-21-2881

In the Annals of Translational Medicine, Volume 8, Web of Science Core Collection was used in three different articles by Fang et al. (1), Liang et al. (2), and Li et al. (3).

The Web of Science Core Collection database is mainly designed for researchers to find literature, but the author uses it to conduct bibliometric research $(4,5)$. In the articles $(1,2)$, keywords were searched in the topic field including terms of title, abstract, author keywords, and KeyWords Plus. The "front page" (including the document title, the abstract, and the author keywords) as a filter has been proposed in 2012 and applied successfully in many bibliometric kinds of research $(6,7)$.

Using the methods noticed in the two articles by Fang et al. (1) and Liang et al. (2) with "front page" as a filter, 2,068 publications and 7,250 publications were found in each of the articles respectively in Table 1 . As a result, 499 publications (24\% of the 2,068 publications) and 2,239 publications ( $31 \%$ of the 7,250 publications) did not contain searching keywords in their "front page." These results show an unaccepted difference from the results in the two original papers $(1,2)$. It was pointed out that the documents, which can only be searched out by KeyWords Plus, were irrelevant to the topic of a bibliometric study (8), for example highly cited review (9) with 100 citations or more entitled "Autophagy in the cellular energetic balance" (10) and an article entitled "Metformin suppresses intestinal polyp growth in $A p c^{\mathrm{Min} /+}$ mice" (11) do not contain search keywords "mTOR" and "liver" in their "front page" were inappropriate in "Scientometric analysis of mTOR signaling pathway in liver disease" (I) if the search keywords are appropriate in the original paper (1). Similarly, classic article (12) with 1,000 citations or more entitled "The development of Assessment of SpondyloArthritis international Society classification criteria for axial spondyloarthritis (part II): Validation and final selection" (13) and review entitled "Five years of GWAS discovery" (14) do not contain search keywords spondylitis and ankylosing in their "front page" were inappropriate in "Research hotspots and trends analysis of ankylosing spondylitis: A bibliometric and scientometric analysis from 2009 to 2018" (II) if the search keywords are appropriate in the original paper (2).

Similar comments were also published in medicalrelated journals in recent years, for example, Frontiers in Pharmacology (15), Chinese Medical fournal (16), Cleft Palate-Craniofacial Fournal (17), World Neurosurgery (18), Indian Fournal of Surgery (19). However, the article entitled "Research trends and performances of breast reconstruction: A bibliometric analysis" by $\mathrm{Li}$ et al. (3) published in the Annals of Translational Medicine, used the bibliometric method with "front page" as a filter to improve the accuracy of the data in the paper. Sixteen percent of the total documents that do not contain search keywords in their "front page" were ignored in the article (3).

The authors in the two papers $(1,2)$ used inappropriate methods to publish bibliometric papers in the Ann Transl 
Table 1 Publications found using "front page" as a filter

\begin{tabular}{llll}
\hline Authors & Searching keywords & Conditions & TP (\%) \\
\hline Fang et al. (1) & "mTOR" and "liver" & WoSCC, Topic, 2004-2018 & 499 publications (24\% of the 2,068 publications) \\
Liang et al. (2) & spondylitis and ankylosing & $\begin{array}{l}\text { WoSCC, Topic, articles and review, } \\
\text { English, 2009-2018 }\end{array}$ & 2,239 publications (31\% of the 7,250 publications) \\
\hline
\end{tabular}

TP, number of publications without searching keywords in "front page".

Med. This may result in misleading readers of the journal $(19,20)$. Authors have the responsibility to use accurate methods in their publications.

\section{Acknowledgments}

Funding: None.

\section{Footnote}

Provenance and Peer Review: This article was a standard submission to the journal. The article has undergone external peer review.

Conflicts of Interest: The author has completed the ICMJE uniform disclosure form (available at https://dx.doi. org/10.21037/atm-21-2881). The author has no conflicts of interest to declare.

Ethical Statement: The author is accountable for all aspects of the work in ensuring that questions related to the accuracy or integrity of any part of the work are appropriately investigated and resolved.

Open Access Statement: This is an Open Access article distributed in accordance with the Creative Commons Attribution-NonCommercial-NoDerivs 4.0 International License (CC BY-NC-ND 4.0), which permits the noncommercial replication and distribution of the article with the strict proviso that no changes or edits are made and the original work is properly cited (including links to both the formal publication through the relevant DOI and the license). See: https://creativecommons.org/licenses/by-nc-nd/4.0/.

\section{References}

1. Fang J, Pan L, Gu QX, et al. Scientometric analysis of mTOR signaling pathway in liver disease. Ann Transl Med 2020;8:93.
2. Liang $M$, Meng $Y$, Zhou S, et al. Research hotspots and trends analysis of ankylosing spondylitis: a bibliometric and scientometric analysis from 2009 to 2018. Ann Transl Med 2020;8:1445.

3. Li Y, Wang X, Thomsen JB, et al. Research trends and performances of breast reconstruction: a bibliometric analysis. Ann Transl Med 2020;8:1529.

4. Ho YS. Comment on Chen, J.; Su, Y.; Si, H.; Chen, J. Managerial Areas of Construction and Demolition Waste: A Scientometric Review. Int. J. Environ. Res. Public Health 2018, 15, 2350. Int J Environ Res Public Health 2019;16:1837.

5. Ho YS. Rebuttal to: Li et al. "Dynamic analysis of international green behavior from the perspective of the mapping knowledge domain," Environmental Science and Pollution Research, vol. 26, pp. 6087-6098. Environ Sci Pollut Res Int 2020;27:22127-8.

6. Fu HZ, Wang MH, Ho YS. The most frequently cited adsorption research articles in the Science Citation Index (Expanded). J Colloid Interface Sci 2012;379:148-56.

7. Usman M, Ho YS. A bibliometric study of the Fenton oxidation for soil and water remediation. J Environ Manage 2020;270:110886.

8. Fu HZ, Ho YS. Top cited articles in thermodynamic research. J Eng Thermophys-Rus 2015;24:68-85.

9. Ho YS. A bibliometric analysis of highly cited articles in materials science. Current Science 2014;107:1565-72.

10. Singh R, Cuervo AM. Autophagy in the cellular energetic balance. Cell Metab 2011;13:495-504.

11. Tomimoto A, Endo H, Sugiyama M, et al. Metformin suppresses intestinal polyp growth in ApcMin/+ mice. Cancer Sci 2008;99:2136-41.

12. Long X, Huang JZ, Ho YS. A historical review of classic articles in surgery field. Am J Surg 2014;208:841-9.

13. Rudwaleit M, van der Heijde D, Landewé R, et al. The development of Assessment of SpondyloArthritis international Society classification criteria for axial spondyloarthritis (part II): validation and final selection. Ann Rheum Dis 2009;68:777-83. 
14. Visscher PM, Brown MA, McCarthy MI, et al. Five years of GWAS discovery. Am J Hum Genet 2012;90:7-24.

15. Ho YS. Commentary: Trends and Development in Enteral Nutrition Application for Ventilator Associated Pneumonia: A Scientometric Research Study (1996-2018). Front Pharmacol 2019;10:1056.

16. Ho YS. Comments on Research trends of macrophage polarization: a bibliometric analysis. Chin Med J (Engl) 2019;132:2772.

17. Ho YS. Comment on: "A Bibliometric Analysis of Cleft Lip and Palate-Related Publication Trends From 2000 to 2017" by Zhang et al. (2019). Cleft Palate Craniofac J 2020;57:395-6.

Cite this article as: Ho YS. Some comments on using of Web of Science Core Collection for bibliometric studies in Ann Transl Med. Vol. 8. Ann Transl Med 2021;9(15):1218. doi: 10.21037/atm-21-2881
18. Ho YS. Letter to the Editor Regarding "Bibliometric and Visualized Analysis of Stem Cells Therapy for Spinal Cord Injury Based on Web of Science and CiteSpace in the Last 20 Years". World Neurosurg 2020;140:423-7.

19. Ho YS. Comment on: "A Bibliometric Analysis and Visualization of Medical Big Data Research" Sustainability 2018, 10, 166. Sustainability 2018;10:4851.

20. Ho YS. Comments on: Li et al. (2020) 'Knowledge structure of technology licensing based on co-keywords network: A review and future directions' International Review of Economics \& Finance, 66: 154-165. Int Rev Econ Finance 2021;75:267-8. 